\title{
FACTORS INFLUENCING THE SUCCESS OF CHOLESTEATOMA SURGERY: A POSTOPERATIVE REVIEW
}

\author{
Milan Stankovic ${ }^{1}$, Petar Stankovic ${ }^{2}$ \\ ${ }^{1}$ University ORL Clinic, Nis, Serbia \\ ${ }^{2}$ Medical Faculty, Nis, Serbia
}

\begin{abstract}
Objective: To review the audiological results of patients surgically treated for cholesteatoma.

Patients and Methods: A retrospective study of patients operated for acquired middle ear cholesteatoma during the period 1990-2002 was performed. A total of 758 patients were followed in the short term and 611 patients in the long term. Localization of cholesteatoma was classified as attic, sinus, or tensa. Closed tympanoplasty was performed as the single procedure of choice on all the children, and reoperation or conversion to open tympanoplasty was made later if needed. Adult patients were treated with single classical canal wall up (CWU), or wall down (CWD), according to the propagation of disease and condition of the middle ear. Preoperative and postoperative air-bone gap (ABG), and pure tone average (PTA), were compared.

Results: Considering all the patients, hearing improvement (reduction of $\mathrm{ABG}$ ) amounted to $20 \mathrm{~dB}$ in the short term and 18 $\mathrm{dB}$ over the long term. Preoperative hearing level was significantly worse for the CWD than for the intact canal wall (ICW) technique. The ABG closure was much better in the group with attic cholesteatoma. Revision operations and bilateral cholesteatoma gave worse total postoperative hearing. Damage of auditory ossicles correlated well with total preoperative and postoperative results.
\end{abstract}

Conclusions: The audiological results of cholesteatoma surgery are preserved during long-term follow-up. Poorer preoperative hearing level, CWD tympanoplasty, bilateral cholesteatoma, and ossicular damage, as well as revision surgery, were associated with reduced gains in hearing with surgical management.

\section{ФАКТОРЫ, ВЛИЯЮЩИЕ НА УСПЕХ ХИРУРГИЧЕСКОЙ ОПЕРАЦИИ ХОЛЕСТЕАТОМЫ: ПОСЛЕОПЕРАЦИОННЫЙ ОБЗОР}

\section{Резюме}

Цель: рассмотреть аудиологические результаты пациентов, которым была проведена хирургическая операция холестеатомы.

\begin{abstract}
Пациенты и Методы: Было выполнено ретроспективное исследование пациентов, прооперированных по причине приобретенной холестеатомы среднего уха в период 1990-2002. В общей сложности под наблюдением находились 758 пациентов в течение короткого времени и 611 пациентов в долгосрочной перспективе. Локализация холестеатомы была классифицирована как в области аттика, синуса, или tensa. Тимпанопластика закрытого типа была выполнена у всех детей, и повторная операция или открытая тимпанопластика были сделаны позже, если это было необходимо. Лечение взрослых пациентов проводилось только с помощью классической тимпанопластики закрытого типа (CWU), или открытого (CWD), в соответствии с прогрессом болезни и состоянию среднего уха. Были сравнены дооперационный и после операционный костно-воздушный интервал (ABG), и пороговая слуховая чувствительность по средней величине уровня звука (РТА).
\end{abstract}

Результаты: Принимая во внимание всех пациентов, улучшение слуха (сокращение ABG) составляло 20 дБ в течении короткого времени и 18 дБ в долгосрочной перспективе. Дооперационный уровень слуха был значительно хуже при CWD, чем при технике интактной канальной мастоидэктомии (ICW). Костно-воздушный интервал ABG было намного лучше в группе холестеатомы аттика. Повторные операции и двусторонний холестеатома привели к хужему после операционному слуху. Повреждение слуховых косточек было соотносимо с полными дооперационными и после операционными результатами.

Заключение: Аудиологические результаты операции холестеатомы сохраняются на протяжении длительного времени наблюдения. Более слабый дооперационный уровень слуха, CWD тимпанопластика, двусторонняя холестеатома, и повреждение слуховых косточек, так же как дополнительная хирургическая операция были связаны с уменьшением эффекта улучшения слуха оперативным путем. 


\title{
FACTORES QUE INFLUYEN EL ÉXITO DE CIRUGÍA DE COLESTEATOMA: UNA REVISIÓN POSTVIGENTE
}

\begin{abstract}
o
Objetivo: Examinar los resultados audiologicos de pacientes tratados quirúrgicamente por colesteatoma.

Pacientes y Métodos: Fue realizado un estudio retrospectivo de pacientes operados por la causa de colesteatoma adquirida del oído medio durante el período 1990-2002. En total, 758 pacientes fueron observados durante poco tiempo y 611 pacientes durante mucho tiempo. La localización de colesteatoma fue clasificada como atical, seno, o tensa. Timpanoplastia cerrada fue realizada en todos los niños, y la nueva operación o timpanoplastia abierta fueron hechas más tarde cuando fueron necesarios. Los pacientes adultos fueron tratados con clásica timpanoplastia cerrada (CWU), o abierta (CWD), según el progreso de la enfermedad y la condición del oído medio. Fueron comparados la brecha aire-hueso previgente y postvigente (ABG), y la media de tonos puros (PTA).
\end{abstract}

Resultados: Considerando todos los pacientes, mejoramiento del oído (la reducción de ABG) ascendió a 20 dB durante poco tiempo y $18 \mathrm{~dB}$ durante más largo tiempo. El nivel de oído previgente era considerablemente peor en CWD que en mastoidectomía con pared del canal intacta (ICW). El cierre del ABG era mucho mejor en el grupo con el colesteatoma atical. Las operaciones de revisión y colesteatoma bilateral resultaron en el oído postvigente peor. En total daño de la cadena osicular era correlacionado con resultados previgentes y postvigentes.

Conclusión: Los resultados audiologicos de la cirugía de colesteatoma son conservados durante larga observación. Más pobre nivel del oído previgente, timpanoplastia CWD, colesteatoma bilateral, y daño de huesecillos, así como cirugía de revisión son relacionados con la reducción del mejoramiento del oído por la cirugía.

\section{Background}

The improvement of hearing after tympanoplasty is affected by many factors, such as age, type, and localization of the pathological process in the middle ear, status of the Eustachian tube, skill of the surgeon, and the surgical technique used [1]. Lack of a standard reporting protocol for tympanoplasty is one of the most important reasons for heterogeneity of existing reports on prognostic factors and the role of various pathologic and surgical parameters. Most reports are based on short- or mediumterm outcomes, and long-term observations are rare [2]. The aim of the present study was to assess the results of cholesteatoma surgery, comparing short- and long-term audiological outcomes, and to measure the influence of various prognostic factors.

\section{Patients and Methods}

A group of 758 patients with acquired middle ear cholesteatoma were followed for a short period ( 1 year) after their operation, and 611 of them were followed up for a long-term assessment (more than 5 years afterwards). The localization of cholesteatoma was classified as attic, sinus, or tensa [3]. The types of damage to the auditory ossicles were: malleus and stapes present $(\mathrm{M}+\mathrm{S}+)$; malleus present, stapes absent $(\mathrm{M}+\mathrm{S}-)$; malleus absent, stapes present $(\mathrm{M}-\mathrm{S}+)$; and malleus and stapes absent (M-S-) [4].

Closed tympanoplasty was always performed as the procedure of choice on all the children, and reoperation (recurrent cholesteatoma, resuppuration, and $\mathrm{AB}$ gap of more than $20 \mathrm{~dB}$ ) or conversion to open tympanoplasty (inability to control disease using the closed technique) was done later if needed. Adult patients were treated with single classical canal wall up, or wall down, according to the propagation of disease and condition of the middle ear. Extensive disease, small mastoid, and damaged posterior wall were the main indications for wall down surgery, while in all other cases the closed technique was employed. Manubrium mallei and stapedial suprastructure, when present, were preserved, and used for better hearing by supporting shaped autologous incus. In cases with significant ostitic incudes, they were removed and interposition was performed using tragal cartilage. Reconstruction of attic or reinforcement of tympanic membrane in other parts was made with palisade conchal cartilage [5]. Indications for reoperations were the same.

Hearing results were reported in conformity with guidelines of the American Academy of Otolaryngology - Head and Neck Surgery Committee of Hearing and Equilibrium for the evaluation of results of treatment of conductive hearing loss. Hearing results were measured for air-bone gap (ABG), and pure tone average (PTA) audiometry. Successful hearing was defined as a postoperative ABG of 20 $\mathrm{dB}$ or less, and PTA of $30 \mathrm{~dB}$ or less. ABG and PTA were analyzed at $0.5,1,2$, and $3 \mathrm{kHz}[6]$.

Type of surgical therapy, localization of cholesteatoma, revisions, bilaterality of disease, damage of auditory ossicles, and learning curve were analyzed. Paired $t$-test was used to investigate the differences between groups ( $p<0.05$ was deemed statistically significant). 


\section{Results}

Overall, short-term results after cholesteatoma surgery were successful (ABG under $20 \mathrm{~dB}$ ) in $75.2 \%$ of cases for attic, $68.2 \%$ for sinus, and $59.6 \%$ for tensa cholesteatoma. The success rate measured by PTA was similar. Long-term hearing gradually became worse for all the localizations of cholesteatoma: $68.2 \%$ for attic, $63.3 \%$ for sinus, and $51.8 \%$ for tensa cholesteatoma (Table 1).

Considering all the patients, hearing improvement, presented as a reduction of $\mathrm{ABG}$, amounted to $20 \mathrm{~dB}$ for shortterm assessment and deteriorated to $18 \mathrm{~dB}$ for long-term follow-up $(p<0.05)$. Paired $t$-test confirmed postoperative improvement of hearing for all the analyzed groups of influential factors.

Postoperative hearing improvement was significantly better for intact canal wall (ICW) tympanoplasty at long-term follow up. The ABG closure was much better in the group with attic cholesteatoma than for other localizations. Also, the ICW technique gave better results for attic and sinus, while for tensa cholesteatoma CWD resulted in better postoperative hearing but without significant differences.

Comparing preoperative hearing level (ABG and PTA), we found significantly worse values for tensa cholesteatoma than for other localizations of the pathological process. At follow-up, surgical results were good in all the localizations of cholesteatoma (ABG closure in $21.5 \mathrm{~dB}$ for attic, $18.7 \mathrm{~dB}$ for tensa, and $19.6 \mathrm{~dB}$ for tensa cholesteatoma). Both short- and long-term improvements were significantly worse for sinus and tensa cholesteatoma than for attic cholesteatoma. This was also confirmed for the association of cholesteatoma localization and surgical technique and revision operations, but it was not significant for cholesteatoma localization and bilateral process or damage of auditory ossicles (Table 1).

Revision operations performed because of recurrent cholesteatoma produced even worse total postoperative hearing, especially after 5 years $(p<0.001)$. Bilateral cholesteatoma was associated with the worst total hearing improvement, both at short- and long-term study $(p<0.001)$.

Damage of auditory ossicles correlated well with total preoperative and postoperative results $(p<0.001)$. Absence of malleus and/or stapes gave worse hearing level before surgery, and after tympanoplasty the improvement was less, with more deterioration in the long-term.

\section{Discussion}

It is generally accepted that the long-term results of tympanoplasty are not as good as the short-term results. The degree of otorrhoea, the status of auditory ossicles, tympanic membrane perforation, middle ear mucosa, cholesteatoma, experience of the surgeon, re-aeration of the reconstructed middle-ear cavity, and presumed incomplete removal are considered important for success [7].

The results of middle-ear surgery are frequently reported in terms of closure of the air-bone gap and improvement in air-conduction threshold (in $\mathrm{dB}$ ) as they validly reflect technical success. In this study preoperative hearing thresholds were higher in tensa cholesteatoma, older patients, revision operations, bilateral process, and more intense ossicular damage. The potential for hearing gain is greatest for patients having larger preoperative ABGs. Poor hearing before surgery is associated with poor hearing after surgery, regardless of anatomy and type of tympanoplasty [8]. We also confirmed worse results for the groups with worse preoperative hearing level.

Both intact canal wall (ICW) and canal wall down (CWD) techniques are used for surgical treatment of cholesteatoma, with different preferences among otosurgeons. According to some, the results support the continued use of ICW mastoidectomy with tympanoplasty. If planned second-stage surgery is necessary, the long-term results of an ear with useful hearing and few problems with chronic medical care are obtained. But, for both the ICW and CWD techniques, long-term follow-up is mandatory in order to obtain adequate results. Both the patient and the surgeon should be engaged in follow-up [9-11]. This study confirmed that the ICW technique can be performed in most cholesteatoma cases, especially in children, with even significantly better hearing outcomes than for the CWD technique.

In this study we focused only on hearing results obtained after cholesteatoma surgery. We found that the hearing results of autologous ossiculoplasty without recurrent disease were long-term stable, without statistical difference from the short-term results. This implies that postoperative hearing deterioration should be mainly attributed to recurrent middle-ear pathology. Worse hearing results were obtained after surgery for tensa cholestatoma, bilateral disease, worse preoperative hearing, and more intense damage of auditory ossicles. This implies that advanced disease, and bad tubal function, as seen in tensa cholesteatoma, cause significantly worse hearing outcomes.

Residual and, more frequently, recurrent cholesteatoma were seen in a total of $23.9 \%$ of patients, or in $73.4 \%$ of revision tympanoplasties. In the rest, $26.4 \%$ of revisions we documented granulations, ossicular damage, or defect of neomembrane, as the cause of bad hearing resulting from the primary operation. Age, bilateral disease, site of cholesteatoma, and ossicular damage correlated to the results of revision operations.

Long-term follow-up confirmed a slight decrease in hearing as a consequence of evolution of pathologic processes. CWD technique, revision operations, bilateral process, and ossicular damage were associated with worse long-term results. Such data are important for preoperative prognosis of hearing outcome, and for counseling patients.

Attic reconstruction with cartilage gives good results in preventing postoperative retraction pockets. Bone pate scutumplasty is similarly effective. For both sinus and tensa cholesteatoma, surgery using the palisade technique was found to be superior in respect to the prevention of drum retraction and perforation, especially in ears with poor tubal function or in atelectatic ears $[12,13]$. Routine reconstruction of attic with cartilage resulted in a low level of postoperative recurrent disease in this series of patients. 
Stankovic M. and Stankovic P. - Factors influencing...

Table 1. Improvement of ABG (dB) after tympanoplasty in different localizations of cholesteatoma.

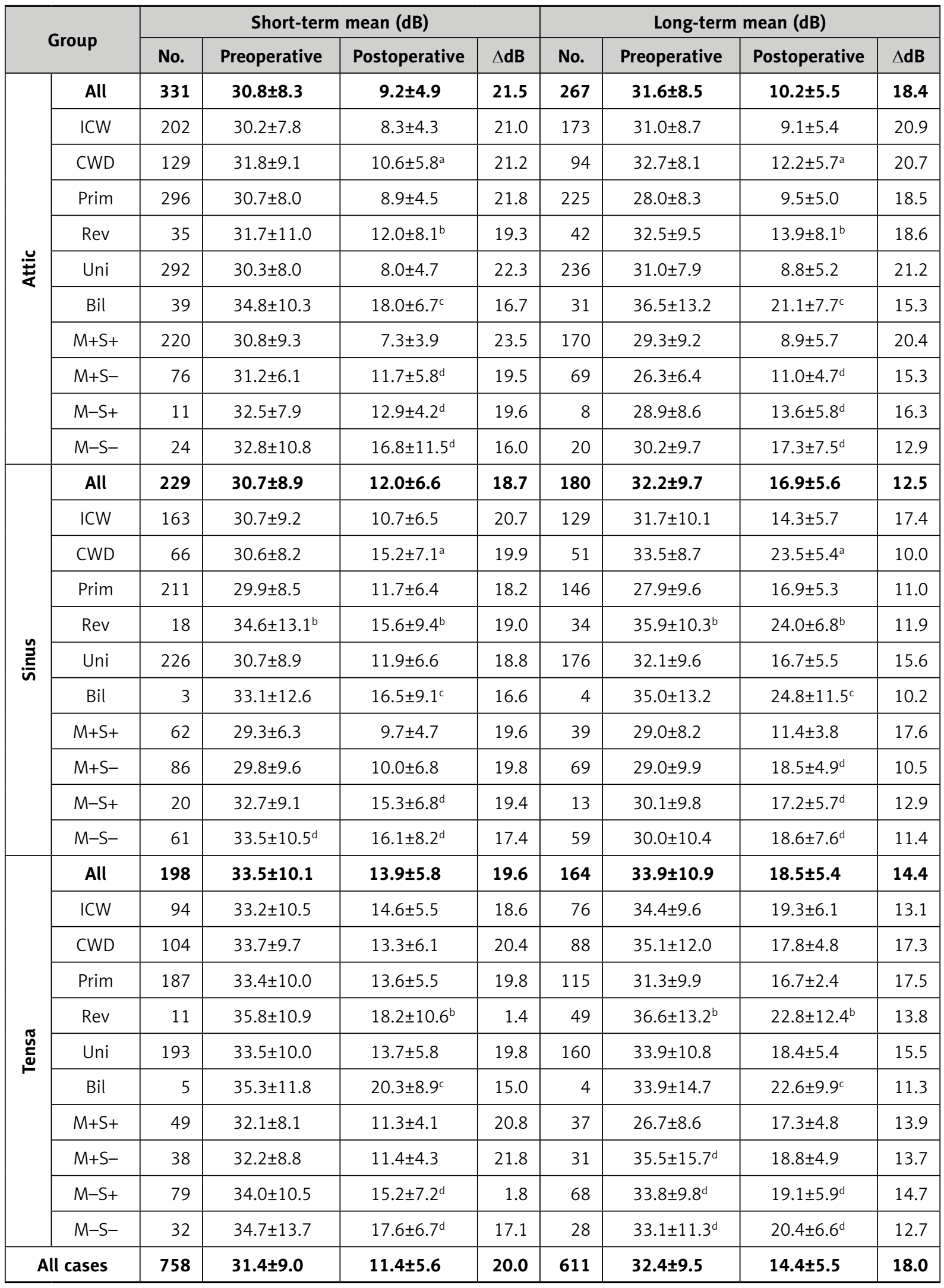

Significantly different $(p<0.05)$ from: ${ }^{a}-I C W ;{ }^{b}-$ primary operation; ${ }^{c}-$ unilateral cholesteatoma; $^{d}-M+S+$.

CWD - canal wall down; ICW - intact canal wall; M - malleus; S - stapes; "+" - present; "-" - absent; Prim - primary operation; Rev - revision; Uni - unilateral; Bil - bilateral cholesteatoma. 
According to some otosurgeons, the functional hearing results of revision surgery for chronic otitis media with cholesteatoma during a long-term follow-up period are similar to primary cases [14]. When a partial ossicular replacement prosthesis (PORP) is required, results are worse and they depend on canal wall status [15]. Recurrent disease appeared either in the attic, or developed from a retraction pocket in a similar manner to patients receiving primary surgery. However, the results after revisions were worse than after primary operations, especially in the long-term period.

Strict reporting protocols, comparison of clinical studies, and long-term follow-up could further clarify the importance of some prognostic factors and thus improve the success rate of tympanoplasties. Statistical study of different factors influencing the success of cholesteatoma surgery enabled precise documentation of their individual or combined contribution to hearing outcome of tympanoplasties. We found that the type of surgical therapy (ICW versus CWD), localization of cholesteatoma, age of patients, revisions, bilaterality of disease, and damage of auditory ossicles were significant factors for audiological outcomes of cholesteatoma surgery.

\section{Conclusions}

Long-term follow-up shows that the results of cholesteatoma surgery can be preserved. Poorer preoperative hearing level, CWD tympanoplasty, bilateral cholesteatoma, and ossicular damage, as well as revision surgery, were associated with reduced gains in hearing with surgical management.

\section{References:}

1. De Vos C, Gersdorff M, Gérard JM: Prognostic factors in ossiculoplasty. Otol Neurotol, 2007; 28: 61-67

2. Leonetti JP, Marzo SJ, Beauchamp MM et al: Long-term results with operated sinus tympani retraction cholesteatoma. Otolaryngol Head Neck Surg, 2006; 135: 152-54

3. Tos M, Lau T: Late results of surgery in different cholesteatoma types. ORL J Otorhinolaryngol Relat Spec, 1989; 51: 33-49

4. Iurato S, Marioni G, Onofri M: Hearing results of ossiculoplasty in Austin-Kartush group A patients. Otol Neurotol, 2001; 22: $140-44$

5. Stankovic M: Follow up of cholesteatoma surgery: open versus closed tympanoplasty. ORL, 2007; 69: 299-305

6. American Academy of Otolaryngology - Head and Neck Surgery Foundation Inc. Committee of Hearing and Equilibrium guidelines for the evaluation of results of treatment of conductive hearing loss. Otolaryngol Head Neck Surg, 1995; 113: $186-87$

7. Ikeda M, Yoshida S, Ikui A et al: Canal wall down tympanoplasty with canal reconstruction for middle-ear cholesteatoma: post-operative hearing, cholesteatoma recurrence, and status of re-aeration of reconstructed middle-ear cavity. J Laryngol Otol, 2003; 117: 249-55
8. Jeng FC, Tsai MH, Brown CJ: Relationship of preoperative findings and ossicular discontinuity in chronic otitis media. Otol Neurotol, 2003; 24: 29-32

9. Emir H, Ceylan K, Kizilkaya Z et al: Success is a matter of experience. Type 1 tympanoplasty: influencing factors on type 1 tympanoplasty. Eur Arch Otorhinolaryngol, 2007; 264: 595-99

10. Kos MI, Castrillon R, Montandon P, Guyot JP: Anatomic and functional long-term results of canal wall-down mastoidectomy. Ann Otol Rhinol Laryngol, 2004; 113: 872-76

11. Siddiq MA, East DM: Long-term hearing results of incus transposition. Clin Otolaryngol, 2004; 29: 115-18

12. Anderson J, Cayé-Thomasen P, Tos M: A comparison of cartilage palisades and fascia in tympanoplasty after surgery for sinus or tensa retraction cholesteatoma in children. Otol Neurotol, 2004; 25: 856-63

13. Dornhoffer J: Cartilage tympanoplasty: indications, techniques, and outcomes in a 1,000-patient series. Laryngoscope, 2003; 113: $1844-56$

14. Veldman JE, Braunius WW: Revision surgery for chronic otitis media: a learning experience. Report on 389 cases with a long-term follow-up. Ann Otol Rhinol Laryngol, 1998; 107: 486-91

15. Kaylie DM, Gardner EK, Jackson CG: Revision chronic ear surgery. Otolaryngol Head Neck Surg, 2006; 134: 443-50 